Yearbook of Population Research in Finland 34 (1997), pp. 114-126

\title{
Family Dynamics in the Baltic Sea Area
}

\author{
MARKETTA RITAMIES \\ Senior Researcher \\ The Population Research Institute \\ Väestöliitto, The Family Federation of Finland \\ Helsinki, Finland
}

\begin{abstract}
The purpose of this article is to describe family dynamics in 1970-1996 in the five Baltic Sea countries of Sweden, Finland, Estonia, Latvia, and Lithuania. In addition, France, Italy, and Poland will be included in the examination as countries of comparison representing Western, Southern, and Eastern Europe. The development which has occurred in the family formation, childbirth, and dissolution of families in the Baltic Sea countries will be examined using available statistical and research data. They will be used to discuss whether family dynamics in the Baltic Sea area reflects pan-European development and how family formation in the Baltic countries has been affected by earlier cultural and religious traditions, in addition to the impact of the Soviet system.

It has been noted that, in some respects, family formation development in the Baltic Sea countries in 1970-96, concerning the development of the marriage rate, for example, has reflected pan-European development. The countries in this group are, however, quite heterogeneous in regard to their family formation development. Sweden has been a pioneer in change and Finland has usually followed behind somewhat later. In the family formation of the Baltic countries, and above all, in the age at first marriage and the age at first birth, there is clear evidence of the influence of the Soviet system. Nevertheless, there are also features of their family formation which come close to development in Western Europe more than in Eastern European countries, in general. For example, the increasing prevalence in Estonia of extramarital births is most likely a manifestation of the impact of cultural traditions. Traditions apparently have also quickened the unusually rapid change in family formation occurring in the Baltic countries after the collapse of the Soviet system.
\end{abstract}

Keywords: family dynamics, family formation, family dissolution, fertility, Baltic Sea Area, France, Poland, Italy

\section{Introduction and aims of the article}

Family formation in Europe has generally developed in a converging direction after World War II. However, one can also observe differences between the countries in family formation and dissolution, especially in timing. Changes which have occurred in family formation have usually begun in the Nordic countries, with the Western and Southern European countries following. Changes in Eastern Europe have arisen later than in the previous groups (Vikat 1994, 20). Lately it seems that differences between the countries of Europe have increased (Coleman 1996, x-xi).

Family formation in the Eastern European countries has differed in some respects from family formation in Western Europe, but during the Soviet regime it has developed in a convergent direction within the region itself (Coleman 1992, 141-179). Most of the Eastern European countries never accepted the Western countries' model of late marriage, a small nuclear family, 
or remaining single throughout one's life. However, the Baltic countries, for example, had a distinctly Western form of family demography before World War II (Coleman 1996, vi). With the collapse of the Soviet Union in 1989 a completely new situation arose. The possibility opened up for the Eastern European countries to continue their previous traditions and to grow closer to the rest of Europe.

This article examines the development in the last few decades of family formation in the Baltic Sea countries - Sweden, Finland, Estonia, Latvia, and Lithuania. This will give us a picture not only of the family formation development in this area, but of developmental trends in Europe as a whole. This is because the countries being examined represent groups of countries at different stages of European family formation development. Sweden is a Northern European pioneer, while Finland, in some respects - for example, regarding the increase of consensual unions - is closer to the Western European countries. The Baltic countries were part of Eastern Europe up to the end of the 1980s. It is especially interesting to see whether the cultural and religious traditions of the Baltic countries preceding World War II have filtered through the Soviet system into family formation development and whether they have accelerated the rate at which European family formation development has been encompassed in the years following independence.

Family dynamics in the Baltic countries have also been affected, apparently, by the fact that the ratio of the basic nationality to the total population has varied in different countries. Lithuania has been the most homogenous country among them in regard to population. The proportion of Lithuanians in the population, which was 81 percent before World War II, is still at the same level in the 1990s. In Estonia and Latvia, though, the proportion of the countries' own citizens decreased under the Soviet system. The Estonian population, which had numbered 88 percent before the Second World War, totaled only 64 percent in the $1990 \mathrm{~s}$, and the proportion of the Latvian population in the corresponding period went from 77 percent to 54 percent (Statistics Finland 1996, 22). One would expect the impact of the Soviet system on family formation to be visible particularly in the latter two countries.

The dynamics of family formation from 1970 to 1996 in the five Baltic Sea countries will be examined on the basis of existing statistics and research. Their development will be compared to the corresponding development in France, Italy, and Poland. France was chosen for the comparison as a representative of the Western European countries, Italy of Southern Europe and especially of the Catholic countries, and Poland as a representative of the Catholic countries of Eastern Europe. The development which has occurred in family formation will be clarified on the basis of changes in the marriage rate and age at marriage, and in the prevalence of consensual unions. Fertility development is shown by changes in the age at birth and number of children, and the birth of children outside marriage. Development occurring in the dissolution of families is shown by changes in the divorce rate and in new marriages. A lack of comparable data limits the examination, however.

\section{Family formation}

Marked changes have taken place in family formation in Europe since the 1970s. There has been a sharp decrease in the marriage rate and marriages are entered at a continuously later age. This does not mean, however, that there would be a decrease in living in a union. Instead of getting married, it is more and more common for people to start their life together in a consenSual union. Different forms of cohabitation have become the norm for first partnerships for an overwhelming majority of the population, particularly in the Nordic countries and in the Baltic countries. The period between forming a partnership and entering marriage has lengthened (Council of Europe 1996, 18). 


\section{Nuptiality}

Before World War II, the Baltic Sea countries being studied here were all distinguished by the Western European nuptiality behavior described by Hajnal (1965) and characterized by a high age at first marriage and a high proportion of the population that would never marry. The changes of the last few decades have been more apparent in this region than to the east of this region. However, the Baltic countries, which belonged to the East European countries, lived under the Soviet regime after the war, so that different preconditions arose for their family formation development (Vikat 1995, 11).

Partnerships formed at a young age and based on marriage, which were still the predominant form of cohabitation in Europe in the $1960 \mathrm{~s}$, have become more varied and more fragile partnerships in the last few decades. Even so, it did not become more common in 1970-1990 to live without any family ties, instead a greater variety of partnership styles have developed. In most European countries the proportion of 45-54-year-olds who had lived outside marriage is already less than 10 percent, which up to the 1940 s was the borderline distinguishing between Western and Eastern nuptiality behavior. In Finland, for example, the proportion of persons always having lived outside of marriage has diminished since 1970 and was 9.6 percent in 1990-91. In Sweden the corresponding proportion was at its lowest - 5.9 percent - in 1980-81, but it had risen to 8.7 percent by $1990-91$ (Miettinen 1997, 24). The proportions of single women remained low in Eastern Europe up to the late 1980s (Coleman 1992, 151). In 1989 the proportion of single persons in the population in the Baltic countries was slightly under 40 percent, in Sweden it was almost 50 percent, and even in Finland it was rather close to this figure (Statistics Finland, 1996, 23).

In the Baltic Sea countries the type of partnership formation first began to change in Sweden, where nuptiality began its decline at the end of the 1960 s. Sweden was not only a pioneer in partnership changes in the Baltic area: along with Denmark it represents the first countries in all of Europe where the predominance of marriage began to crumble. In the early 1970 s nuptiality was already lower in Sweden than in Finland and, even though the difference between the countries gradually shrunk, in the mid-1990s the Finns still entered marriage more often than Swedes. In fact, the development of nuptiality in Finland resembled the development of the marriage rates in Western European countries, those of France, for example (Figure 1).

Figure 1. Total first marriage rate for women below the age of 50.

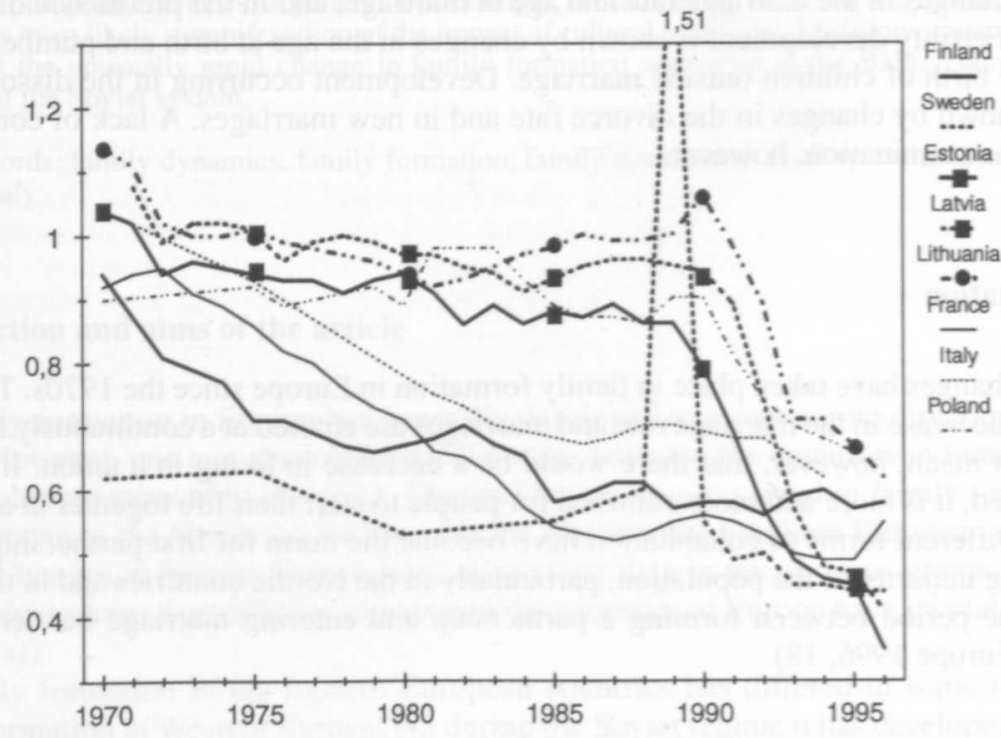

Source: Council of Europe 1997.

Note: In Sweden major reform in legislation concerning the pension system for widows was introduced in $1989 / 90$. causing extensive increase in marriages of never before married persons 1989. 
In the Baltic countries the total first marriage rates for females below the age of 50 remained higher, up to the beginning of the 1990s, than in Sweden and Finland, but they began to decrease rapidly in the $1990 \mathrm{~s}$, after the countries gained independence. In Estonia and Latvia the total first marriage rate dropped below that of Finland in 1993.

Cultural and religious traditions do not seem to have had as clear an impact on the development of nuptiality in the Baltic countries in the $1970 \mathrm{~s}$ and $1980 \mathrm{~s}$ as the Soviet system had. In Catholic Lithuania the development of nuptiality has been similar to that in Poland, but until the beginning of the 1990s it had been higher than in Italy, for example. However, after independence it has been easy for the Baltic countries, apparently because of their traditions, to draw closer to Western Europe. The marriage rate in Lithuania rapidly reached the same level as in the Catholic countries of Southern Europe. Similarly, until 1990, the marriage rates in Estonia, whose culture is closely connected to the Nordic countries, were higher than in Sweden and Finland. There has been rapid change after independence, however. Nuptiality in Estonia, as well as in Latvia, has already dropped below that of Sweden, which represents the lowest European nuptiality level, with Catholic Lithuania staying at only a slightly higher level.

Under the Soviet system, economic factors - for example, those relating to finding housing - affected nuptiality. Unmarried couples were not considered families and could not apply for a joint apartment (Vikat 1994,150). The poor availability of contraceptives has also apparently been related to nuptiality. The contraceptive prevalence rate, which in Sweden and Finland, for example, was close to 80 percent in 1985-90, was 26 in Estonia, 19 in Latvia, and 12 in Lithuania (Unicef 1994, 30). Even though abortions were used in Estonia and Latvia as contraceptive methods, some of those who accidentally became pregnant did marry in this situation. Vikat (1994, 15), for example, notes that in Estonia pregnancy is often a serious incentive to marriage.

\section{Average age at marriage}

The average age at marriage has been shown to correlate closely with the overall propensity to marry and the differences found between countries in the age at marriage prove that there is a difference in nuptiality (Kiernan 1997, 64). In Sweden and Finland this was clearly evident. The age at marriage continued to rise in 1970-96 at the same time that nuptiality decreased. In Sweden, where already in 1970 the age at marriage among women was higher than in Finland, the age at marriage increased by almost five years during the period under study. In Finland, also, the age at marriage rose by more than four years, but it stayed constantly somewhat closer to the age at marriage in France than in Sweden (Figure 2).

In the Baltic countries the correlation between nuptiality and age at marriage is not equally as evident, however. Age at marriage, which in the early 1970s was at the same level in the Baltic countries as in Sweden and Finland, has not risen during the period investigated in the same way as in the Nordic countries. On the contrary, the developmental trend in the Baltic countries was a somewhat declining one up to the 1990s. Even though the age at marriage among women began to rise in the 1990s, especially in Estonia and Latvia, the change was not at all as large as was the decline in the marriage rates.

The development of the age at marriage in the Baltic countries resembles the development in other Eastern European countries, in Poland, for example. The pro-natalist welfare policies in the USSR helped to sustain precocious nuptiality (Coleman 1992,151). The age at marriage in Estonia differs distinctly from that in the Nordic countries. In Lithuania the age at marriage is just as low as in Poland and differs clearly from the Southern European Catholic countries. In Italy, for example, age at marriage in the 1990s was over four years higher than in Lithuania. 
Figure 2. Mean age of women at first marriage.

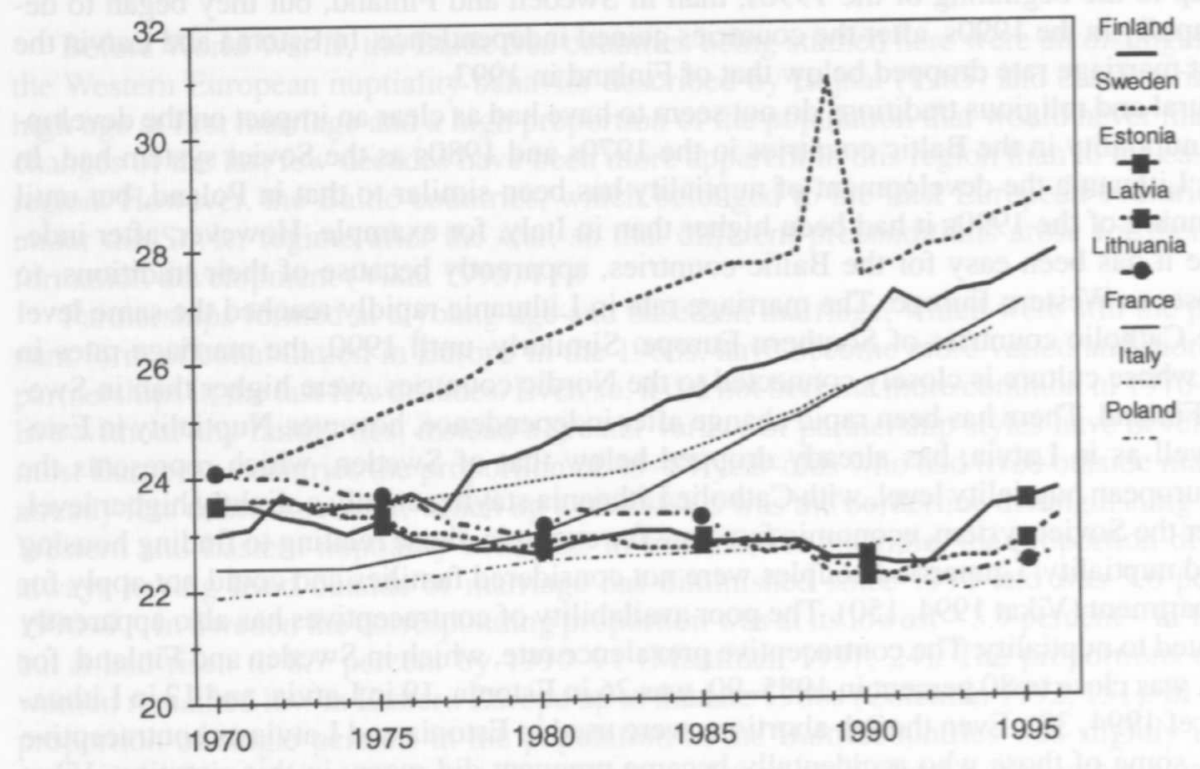

Source: Council of Europe 1997.

Note: In Sweden major reform in legislation concerning the pension system for widows was introduced in 1989/90, causing an extensive increase in marriages of persons never before married in 1989.

\section{Consensual unions}

A decline in nuptiality and a rise in the age at marriage are considered to be due in part to the increase in consensual unions. Even though unofficial cohabitation existed also in previous decades, in Sweden and Finland, for example, consensual unions have usually been invisible in the statistics. Some population groups have had a greater tendency to cohabit unofficially. People who have lived in unregistered partnerships have been, for example, those who had not been able to afford to get married, or who had not officially been divorced from their spouse, or who were against marriage for ideological reasons.

In the current sense - above all as nubile cohabitation - consensual unions began to increase in Sweden in the 1960s and in Finland in the 1970s. Rothenbacher (1995, 3-9) divided the European countries into three groups according to the prevalence of consensual unions. Among the Baltic Sea countries, Sweden belonged to the countries in which consensual unions had already become stabilized. Finland was included in the countries where consensual unions are emerging as a significant way of life, and the East European countries among countries where consensual unions are still rare. Should the Baltic countries be included in the latter group in regard to the prevalence of consensual unions or have consensual unions had some other significance there due to cultural and religious traditions? It is difficult to answer this question because comparative data is lacking. Information on consensual unions in the Baltic countries is not available. Some research data does exist, however, on Estonia, for example (Vikat 1994, 1995).

The proportion of consensual unions of all unions continued to increase in Sweden in the 1980s and in 1989 it was already 27 percent (Statistiska Centralbyrån 1991). In Finland at that time 16 percent of those forming a partnership lived in a consensual union (Tilastokeskus 1991). In both countries consensual unions have clearly concentrated in the young age groups. For example, in Sweden in 1975 the proportion of those in a partnership living in a consensual union was 88 percent in the 16-19-year age group and ten years later this proportion had risen to 93 percent. Even though unofficial cohabitation increased also in the older age groups, the 
proportion of the 30-34-year age group living in a consensual union in 1985 was only 28 percent (Kiernan 1996, 65-66).

Statistics about age at marriage and age at first birth seem to show that consensual unions are more rare in the Baltic countries than in Sweden and Finland. On the other hand, the growth in the proportion of extramarital births seems to signify an increase in consensual unions. Vikat $(1995,10)$ states on the basis of interview data gathered in Tallinn in 1988 that consensual unions would appear to be more common than what the statistics show. Half of the first marriages begun in Tallinn in the 1970s and 1980s started with a consensual union. However, the differences between the Estonians and the Russians living in Estonia were striking in this respect. Among the first unions begun by Estonians, three out of four began with a consensual union, while among the Russians the proportion of consensual unions remained under one-half. However, first consensual unions in Estonia have been relatively short, which according to Vikat $(1995,10)$ is related to a low age at marriage. Currently already almost four out of five Estonians begin their first union with a consensual union (Vikat 1995, 42).

\section{Fertility}

The declining trend in fertility has been a pan-European phenomenon, which began in Northern and Western Europe, but which has gradually also reached the southern parts of the region. Fertility in Southern Europe is now the lowest in Europe. The birth rates in Eastern Europe have also declined dramatically after the collapse of the Soviet Union. While fertility continues to decline in the southern and eastern parts of Europe, there are countries in the area's northern and western parts where the birth rate has been increasing since the mid-1980s, after a period of stability. It can no longer be said that the countries of Europe are converging on a common pattern of fertility (Coleman 1996, 2-3).

The developmental trend in fertility has been quite similar in the Baltic Sea countries in 1970-96, even though there has been a marked difference in the level of fertility in the Baltic countries and in the Nordic countries. In all the countries being studied the total fertility rate declined until 1980, after which it rose in Sweden and Finland until 1990 and in the Baltic countries until 1987. In the 1990s total fertility decreased rapidly in the Baltic countries and also in Sweden, and it was only in Finland that the total fertility rate remained at the same level. While fertility in Sweden and in Finland at the beginning of the period being studied was clearly lower than in the Baltic countries, at the end of the period the situation was the reverse (Figure 3).

Among the Baltic countries there were no large differences in total fertility. Lithuania did diverge from the others in the 1970s with its higher birth rate, but in the 1980s Estonia exceeded this level. In the 1990s Lithuania's total fertility was again greater than in the other Baltic countries. The fertility level in Poland, one of the Eastern European countries, has been on the Same level as in the Baltic countries. In the 1990s the Baltic countries had almost reached the level of the Southern European countries.

\section{Mean age of women at birth of first child and extramarital births}

In Europe in the 1950s and 1960s almost all children were still born within marriages and first children, especially, at a quite early stage of the marriage. In the Nordic countries, in particular, the proportion of pregnant brides has been large. Beginning cohabitation, forming a family, and having children were almost concurrent events (Finnäs 1995, 57-58). The reduction in the mean age at first birth was closely connected with the reduction in the mean age at marriage. The average age at marriage, which began to rise in European countries from the 1970s on, gradually began to lose its close connection with the age at giving birth to the first child. Consensual unions began to increase and the proportion of extramarital births began to grow. 
Figure 3. Total fertility rate 1970-1996.

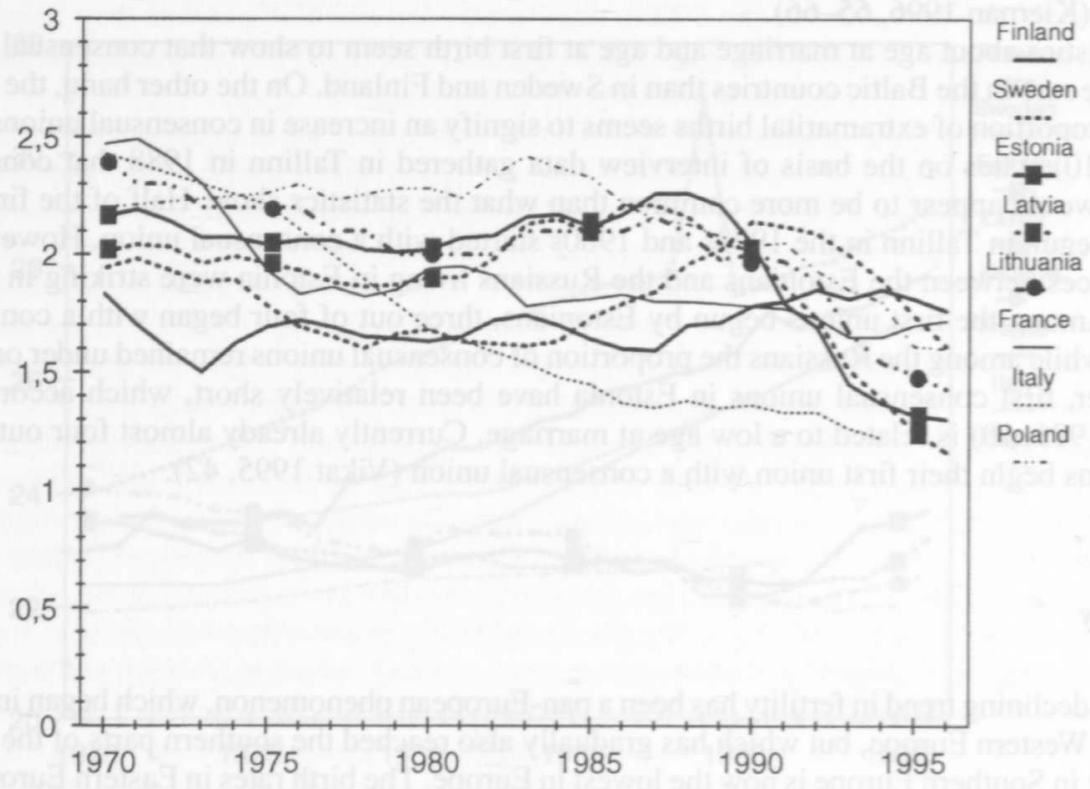

Source: Council of Europe 1997.

Figure 4. Mean age of women at first birth.

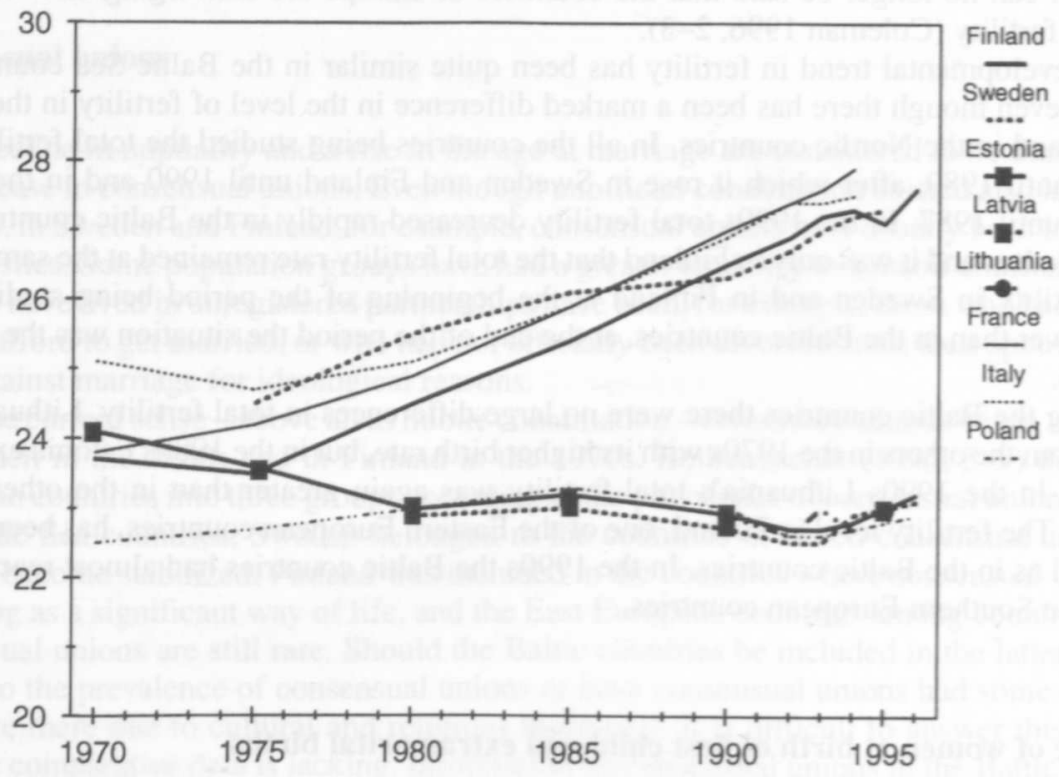

Source: Council of Europe 1997.

The development of age at first birth in 1970-96 in the Baltic countries was completely different from what it was in Sweden and Finland (Figure 4). While in the latter countries, age at birth has risen throughout the period of study, in the former countries it has stayed in place, and has even decreased somewhat. The age at first birth has not risen in the Baltic countries even after independence. 
One of the main reasons for the differing development of the age at first birth in the Baltic countries and in the Nordic countries probably lies, in addition to housing policy, with contraception. Modern, freely available contraceptives have made it possible to postpone childbearing in the Nordic countries to an ever later date, when this has been desired for reasons of further education, work, or other goals. In the Baltic countries modern contraceptives have not been available. Abortion has been the main method of contraception. In Latvia and Estonia, for example, the number of abortions exceeded births in the beginning of the 1990s (Vikat 1995, 25; Central Statistical Bureau of Latvia 1995, 60). Not everyone has wanted to abort an accidental pregnancy, instead the child has been born, either within a marriage or extramaritally. This is apparently the reason why these countries have developed in the same way. In Catholic Lithuania, where there are noticeably fewer abortions than in the other Baltic countries, the age at first birth has probably been low throughout the period being studied, even though this information is not available for the 1970 s and the 1980 s. The impact of the Soviet system is apparent, because the first child in Catholic Italy is currently born almost five years later than in Lithuania or Poland.

Extramarital births have increased in almost all European countries, but there are marked differences between the countries in how prevalent they are. Also in the Baltic Sea area extramarital births fluctuated in 1970-96 from one country to another (Figure 5). In Sweden, where giving birth to a child outside marriage was already more common in 1970 than in other countries, the proportion of extramarital births continued to grow and in 1996 it was already over half of all births.

Figure 5. Extramarital births, per 100 live births 1970-1996.

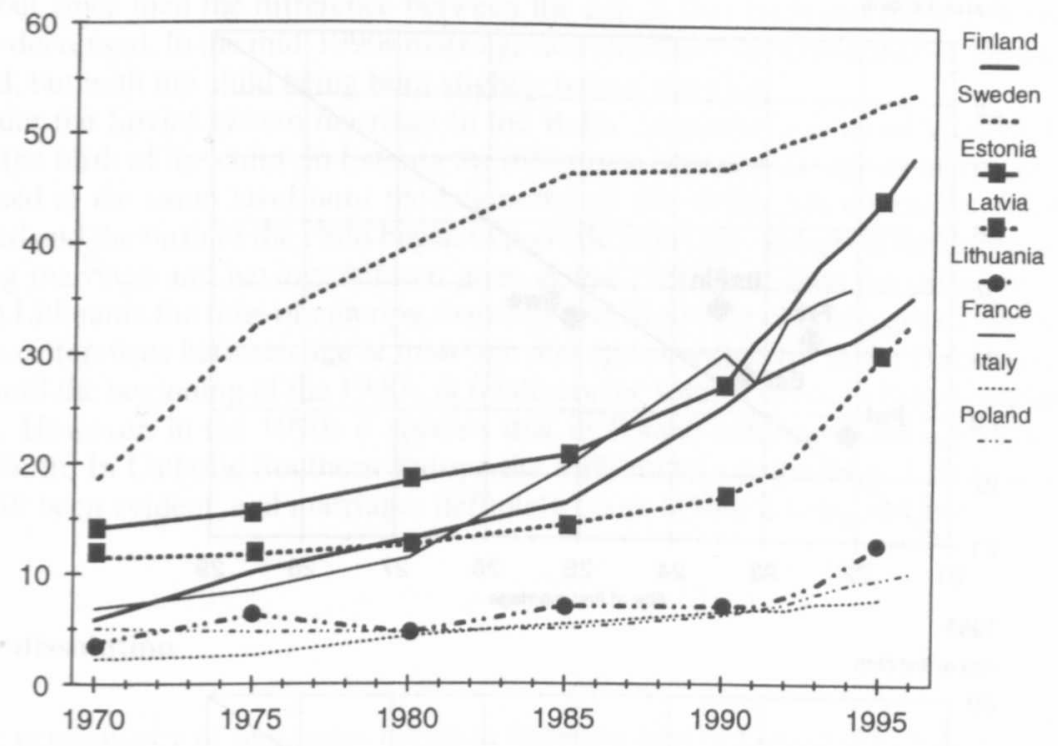

Source: Council of Europe 1997.

In Finland extramarital births have been clearly less frequent than in Sweden throughout the period being examined. In the 1970s rather a small number of children were born outside marriage, but the proportion of extramarital births has continued to grow with the increase in conSensual unions. Rothenbacher (1995, 3-9) considered Finland as belonging to the same group, in regard to the prevalence of consensual unions, as Norway, France, Great Britain, Switzerland, and Austria, for example. In these countries consensual unions are developing into an important way of life and the number of children born outside marriage is also large. In Sweden the consensual union has already become an established way of life and there is a tradition of having children in a consensual union.

In Estonia extramarital births have been more common than in the other Baltic countries 
and especially in the 1990s their proportion has increased rapidly. Estonia is one of the five European countries where the proportion of extramarital births is already almost 50 percent (Council of Europe 1997). Together with the Nordic countries other than Finland, Estonia represents a group of countries where the proportion of marital births is markedly small. Among the Baltic countries, Latvia is closest to Finland in the prevalence of extramarital births. On the other hand, in Catholic Lithuania extramarital births have been rare, but there, too, they have increased in the same way as in other Catholic countries, in Poland and Italy, for example.

In regard to extramarital births, there is no way in the statistics to differentiate between consensual union births and births outside a partnership. According to research, some clarifications can be made. Comparison of results may be difficult, however, as sample sizes, coverage and definitions are likely to vary.

In Sweden about 90 percent of extramarital births are assumed to be consensual union births. In Estonia, also, this proportion is assumed to be about the same, perhaps even greater in the young age groups (Council of Europe 1996, 17). In Latvia it is estimated that about onefifth of all children born in 1992 were born to single women (Unicef, Latvian National Committee 1995, 25). Zvidrins $(1995,17)$, on the other hand, states that only one child out of eleven can be considered illegitimate.

The change in the close connection between the age at first birth and the age at first marriage - because of the increase in consensual unions, for one reason - is confirmed by how the difference between these two figures has developed in 1970-96 (Figure 6).

Figure 6. Mean age at first marriage and mean age at first birth 1975, 1985, and 1995.

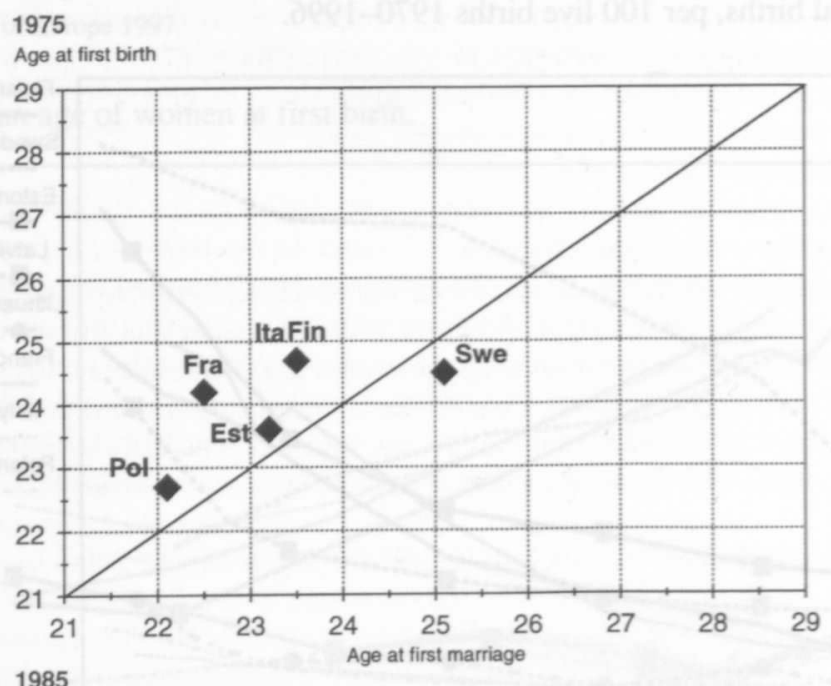

1985

Age at first birth

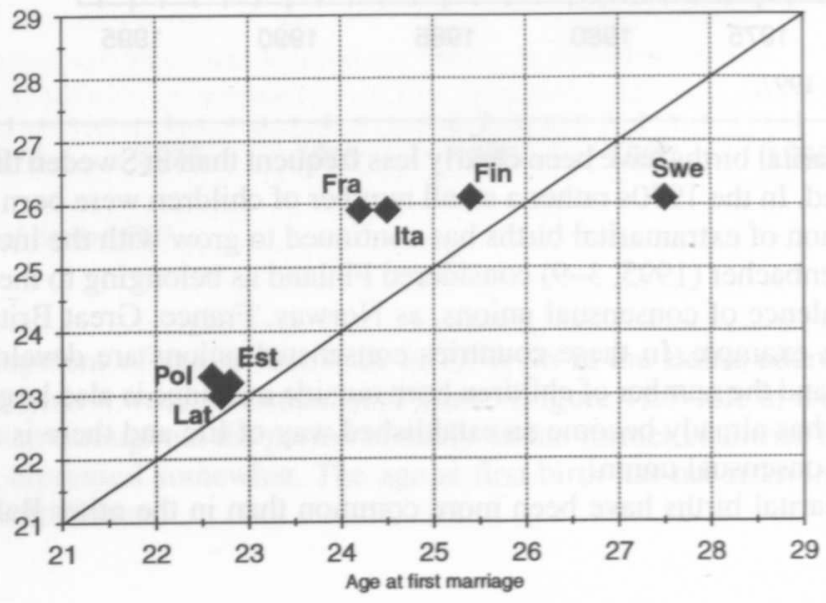




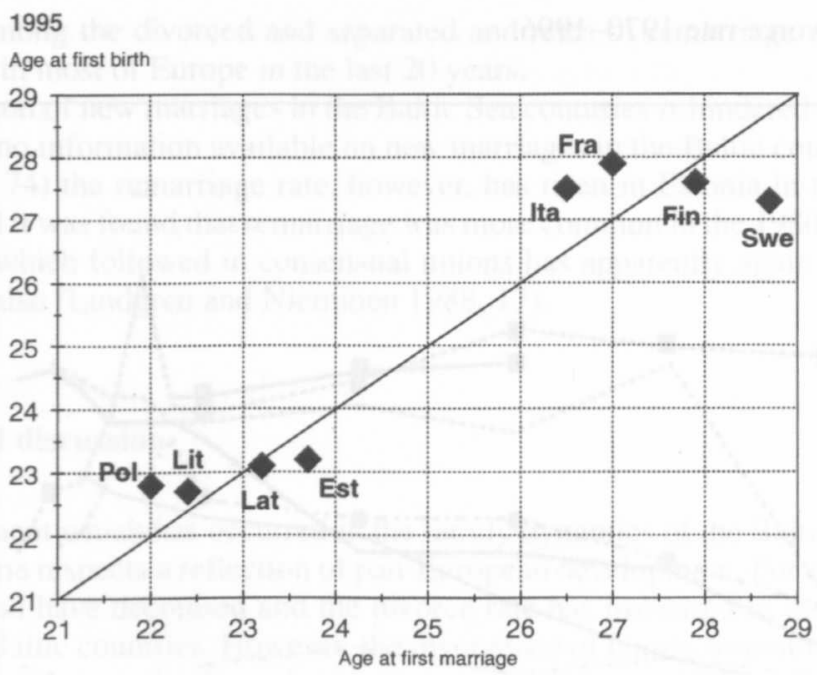

Sweden differs distinctly from the other Baltic Sea countries in that already in the 1970s in Sweden the first child was born before the parents were married, and this trend has become increasingly evident with time. In Finland the first child was born at an ever later age until 1980 , but since then the difference between the age at first birth and the age at marriage has greatly decreased. In the mid-1990s marriage and childbirth occurred almost simultaneously in Finland, but with the child being born slightly before marriage.

Under the Soviet system marriage in the Baltic countries was usually entered somewhat before the birth of the child. In Estonia the difference between the age at marriage and at birth continued at the same level until the beginning of the 1990s, after which a definite change occurred and the birth of the child began to precede marriage. In Latvia the difference between entering marriage and having children grew in the 1980s, but then the difference decreased. Also in Lithuania the time of entering marriage and of having children got closer in the 1990s.

The differences between age at marriage and age at childbirth in the Baltic countries have been, until the beginning of the 1990s, at relatively the same level as in Poland under the Soviet system. However, in the 1990s it appears that in Poland entering marriage clearly precedes giving birth. In Catholic Southern Europe the differences compared to Lithuania and Poland have still been evident, and marriages definitely come before having children.

\section{Family dissolution}

The permanency of marriages began to decrease first in Eastern Europe, where liberal divorce laws were enacted earlier than elsewhere in Europe. An increase in the divorce rate has followed the liberalization of the divorce laws all over Europe. In the 1970s, in addition to the countries of Eastern Europe, the number of divorces was high in Northern Europe also. At the end of the 1980 s the divorce rates leveled out. At that time the divorce rate was highest in England, Denmark and Finland and in some Eastern European countries (Kiernan 1997, 7172).

Sweden's divorce rates rose strongly in the mid-1970s as a result of a new divorce law, and the divorce rate has remained at a high level since then. In Finland, again, divorces had been more rare until the early 1990 s, when the divorce rate rose markedly with the new, more liberal divorce law (Figure 7). 
Figure 7. Total divorce rate 1970-1996.

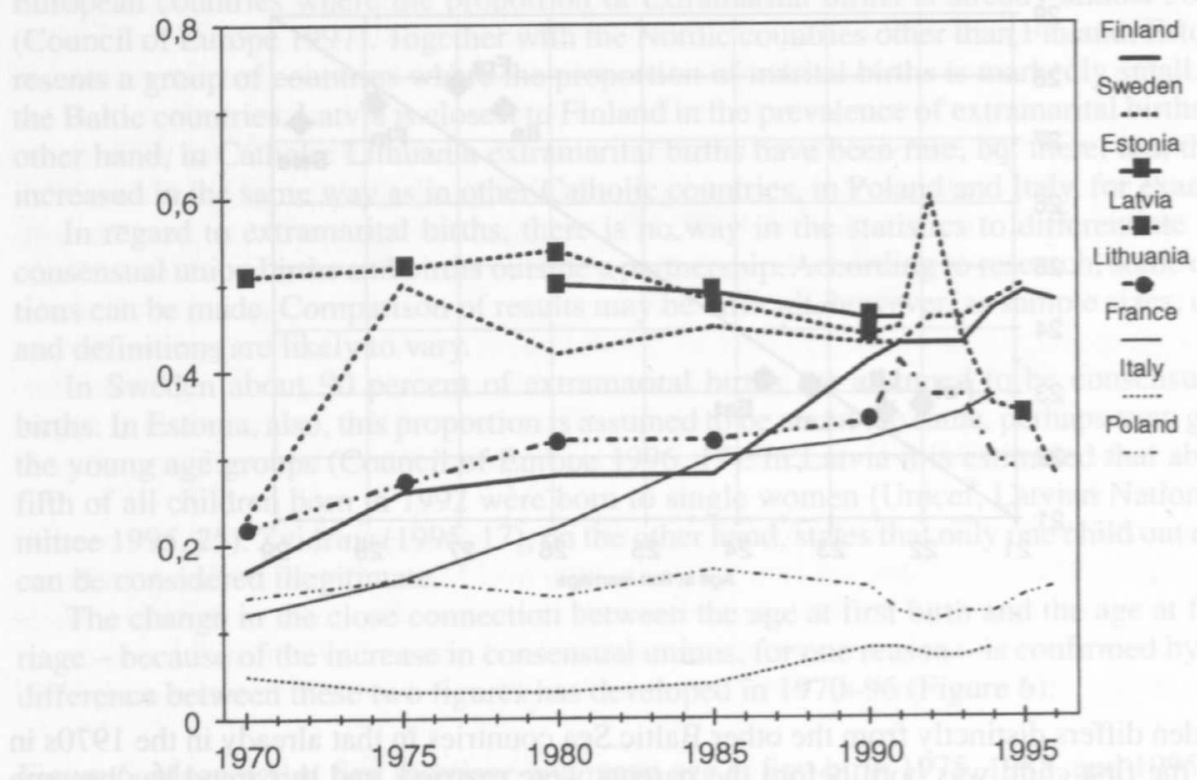

Source: Council of Europe 1997.

The effect of the liberal divorce laws in the Eastern European countries can be seen in Latvia's high divorce rates in the 1970s. Even though data on Estonia is not available until the 1980 s, its development has probably been the same as in Latvia. Later in the 1990s, the divorce rate has decreased in Latvia, however, but in Estonia it has remained almost constantly at the same high level. Lithuania has diverged from the other Baltic countries with its lower divorce rate. Nevertheless, the more liberal attitude toward divorce in Eastern European countries has also had an effect on the divorce rate in Catholic Lithuania. In Italy, for example, the divorce rate is clearly lower. On the other hand, there are also probably more marriages in Italy which, in reality, have ended completely. There spouses are just separated and not divorced.

Divorce statistics can no longer provide us with a complete picture of family dissolution. It should be possible to take consensual divorces into consideration in order to form a clear picture of the permanency of partnerships and the family in today's society. This is not possible using statistics, however, and there is also little research. We do know that consensual unions in Sweden (Hoem and Hoem 1988, 61) and in Finland end up in divorce more often than do marriages. In 1994 and 1995 separations of consensual partnerships in Finland formed 60 percent of moves to separate residences among all consensual and marital unions. Also, almost four times as many consensual unions were formed in these two years as marital unions (Nikander $1996,17,38)$.

The increase in consensual unions especially among the young age groups lowers the marriage rates, with the divorce rates then increasing and growing closer to the marriage rates. In Sweden, Estonia, and Latvia the crude marriage rate and the crude divorce rate are already quite close to each other (a difference of 1.2-1.3). In Finland the difference is greater (a difference 1.9) and in Lithuania the figures are far apart (a difference of 3.0).

The increase in divorces would appear to lead to new marriages. Macura (1994) notes, though, that there is no distinct connection between divorce and remarriage. The decline in first marriage since 1960 was accompanied by a decline in remarriage. The general remarriage rate decreased in Sweden, for example, from 45.9 to 27.0 from 1970 to 1985 , in Finland the corresponding decline was from 37.9 to 25.7 . Also Haskey $(1993,222-223)$ notes that the increase in consensual unions in some Northern and Western European countries, for example, has been 
most common among the divorced and separated and rates of remarriage after divorce have declined sharply in most of Europe in the last 20 years.

The comparison of new marriages in the Baltic Sea countries is hindered again by of a lack of data. There is no information available on new marriages in the Baltic countries. According to Kutsar $(1991,74)$ the remarriage rate, however, has risen in Estonia in the 1970s and the 1980 s. In Finland it was found that remarriage was more common in the 1980s than in Sweden, but the increase which followed in consensual unions has apparently again decreased remarriage in Finland also (Lindgren and Nieminen 1988, 17).

\section{Conclusions and discussion}

The development which has occurred in the family dynamics of the Baltic Sea countries in $1970-96$ is in some respects a reflection of pan-European development. For example, marriage rates in this period have decreased and the divorce rate has increased in the countries in this area, also in the Baltic countries. However, the divergence of family formation development in the Eastern European countries from the development in the rest of Europe until the end of the 1980 s, because of the impact of a different social system, is also apparent in the Baltic countries. The effect of the system is especially evident in the age at first marriage and the age at first birth. The pronatalist population policy of the Soviet Union has favored early marriage and having children, while elsewhere marriage and the time of the first birth have continued to be postponed to a later phase of life.

There are some features in the family formation development in the Baltic countries which support Monnier's and Ryhtarikova's $(1996,156-157)$ observation of a growing uniformity in population development in the Eastern European countries under the Soviet system. For example, the marriage rate, extramarital births, and the birth rate were found to be more uniform in the mid-1980s than two decades earlier. The total fertility rates of Estonia, Latvia, and Lithuania differed from each other in 1970, but in 1985 they were already on the same level. Similarly the age at first marriage has become more uniform in 1970-85.

The effect of the cultural and religious traditions in the Baltic countries before the Second World War is reflected in the development of family formation under the Soviet regime, for example, in how family formation comes closer in some respects to development in Western Europe, more clearly perhaps than in the Eastern European countries, in general. For example, the proportion of extramarital births has increased in Estonia, especially, in the 1970s and 1980s and resembles the development of the proportion of extramarital births in the Nordic countries.

The impact of the cultural traditions of the Baltic countries are perhaps also reflected in the unusually rapid change which has occurred in the development of family formation after independence in the $1990 \mathrm{~s}$. The decrease in the marriage rate has especially been rapid, as well as the decline in the birth rate and the increase in the proportion of extramarital births.

In the last few years it has again been noted that in the family formation of the European countries, the differences between the countries have grown. According to Coleman (1992, 175) the greatest contrasts in population in the Europe of today concern sexual behavior and housing arrangements, for example, divorce, extramarital births, abortions, consensual unions, and postponing or avoiding marriage. These are strongly constrained by national legal and welfare systems, which in turn reflect the preferences of the electorate.

In the Baltic Sea area in the 1990s the differences which have arisen between countries in the divorce rates are more distinct than earlier. In Lithuania and Latvia the divorce rate has decreased, in Sweden and Finland it has grown, and in Estonia it has remained at the same level. The divergence between the countries in postponement of marriage to a later date has also grown. On the other hand, differences in the marriage rate and in the increase in extramarital births have not yet been observed.

Forming a picture of the future development of family formation in the Baltic Sea countries is difficult, because so little time has passed since the Baltic countries gained their independence. Not until later will we be able to see whether Coleman's $(1992,175)$ statement is true, 
that the rise in the proportion of national income spent by governments, and the distinctive differences in national welfare and housing policies, serve to make national demographies different. Then we will also perhaps see how the population distortions, visible in the Eastern European countries since the Second World War, will evidently decrease and be replaced by differences influenced more by the countries' level of economic and social development.

\section{References}

Central Statatistical Bureau of Latvia. Demographic Yearbook of Latvia 1995. Riga 1995.

Coleman, David. 1996. New patterns and trends in European fertility: international and sub-national comparisons. In: Europe's Population in the 1990s, edited by David Coleman, pp. 1-61. Oxford: Oxford University Press.

Coleman, David. 1992. European demographic systems of the future: convergence or diversity? In: Human resources in Europe at the dawn of the 21st century: conference proceedings, International Conference held in Luxembourg from 27 to 29 November 1991 under the aegis of Eurostat and the Luxembourg Government, pp. 137-181. Luxembourg: Office for Official Publications of the European Communities.

Council of Europe. 1996. Recent demographic developments in Europe 1996. Strasbourg: Council of Europe Publishing.

Finnäs, Fjalar. 1995. Entry into consensual unions and marriages among Finnish women born between 1938 and 1967. Population Studies 49(1):57-70.

Hajnal, J. 1965. European marriage patterns in perspective. In: Population in history: essays on historical demography, edited by D.V.Glass and D.E.C. Eversley, pp. 101-143. London: Edward Arnold.

Haskey, John C.V. 1993. Formation and dissolution of unions in the different countries of Europe. In: European population: Volume 2: Demographic dynamics, edited by Alain Blum and Jean-Louis Rallu, pp. 211-229. Montrouge, France: Éditions John Libbey Eurotext.

Hoem, Britta and Jan M.Hoem. 1988. Dissolution in Sweden: the break-up of conjugal unions to Swedish women born in 1936-60. Stockholm Research Reports in Demography, No. 45. Stockholm: Stockholms Universitet. Demografiska avdelningen.

Kiernan, Kathleen K. 1996. Partnership behaviour in Europe: recent trends and issues. In: Europe's population in the 1900s, edited by David Coleman, pp. 62-91. Oxford: Oxford University Press.

Kutsar, Dagmar. 1991. Marriage breakdown in Estonia. Yearbook of Population Research in Finland 29:7382.

Lindgren, Jarl and Mauri Nieminen. 1988. Uudelleen avioituminen (Remarriages in Finland). Väestöntutkimuslaitoksen julkaisuja D, No. 21. Helsinki: Väestötutkimuslaitos, Väestöliitto.

Macura, Miroslav, Edith Adams, and D. Holzer-Zelazewska. 1994. Changing patterns of first marriage, divorce and remarriage in Europe and North America. In: Ageing and the family: proceedings of the United Nations International Conference on Ageing Populations in the Context of the Family, Kitakyushu (Japan), 15-19 October, 1990, pp. 45-60. New York: United Nations.

Miettinen, Anneli 1997. Work and family: data on women and men in Europe. Working Papers E 2/1997. Helsinki: The Population Research Institute, The Family Federation of Finland.

Monnier, A. and J. Rychtarikova. 1992. The division of Europe into East and West. Population, English Selection, Vol. 4. 129-159

Nikander, Timo. 1996. Perheiden muodostuminen ja hajoaminen: avo- ja avioparien yhteen ja erilleen muuutto (Family formation and dissolution: moving into and out of consensual and marital unions). Population, No 17. Helsinki: Statistics Finland.

Rothenbacher, Franz. 1995. Household and family trends in Europe: from convergence to divergence. EURODATA Newsletter 1:3-9.

Statistics Finland. 1996. The Baltic and the Nordic Countries: a collection of statistical data. Compiled by Central Statistical Bureau of Latvia. Suomen lähialueet: erikoisraportti. Helsinki: Statistics Finland.

Statistiska Centralbyrån. 1991. Folkmängd 31 dec 1990 enligt indeldningen 1 jan 1991: del 3: fördelning efter kön, ålder, civilstånd och medborgarskap i kommuner $\mathrm{mm}$. Stockholm.

Tilastokeskus. Avoliitossa elävät = sambor 1989 (Consensual unions 1989). Väestö 1991, No. 1. Helsinki: Tilastokeskus.

Unicef. 1995. Children and families in Latvia. Riga: Unicef, Latvian National Committee.

Vikat, Andres. 1994. Family formation in Estonia. Publication of the Finnish Demographic Society, No. 15. Helsinki: Finnish Demographic Society.

Vikat, Andres. 1995. Perheellistyminen Virossa ja Suomessa (Family formation in Estonia and Finland). Tutkimuksia, No. 214. Helsinki: Tilastokeskus

Zvidrins, Peteris. 1995. The dynamics of fertility and demographic determinants, In: Humanities and Social Sciences, Latvia: demographic situtation in Latvia 1995, 2(7), pp.17-28. Riga: University of Latvia. 